\title{
An Antioxidant Marker, Aminolevulinic Acid Dehydratase, was Correlated with Bone Turnover Activity
}

\author{
Mulyana $^{1, *}$, Mansyur Arif ${ }^{1}$, Dewi Muliaty ${ }^{2}$ \\ ${ }^{1}$ Post Graduate Program in Clinical Biochemistry,, Faculty of Medicine, Hasanuddin University, \\ Jl. Perintis Kemerdekaan Km.10. Makassar, Indonesia \\ ${ }^{2}$ Prodia Clinical Laboratory, JI. Kramat Raya 150, Jakarta, Indonesia \\ ${ }^{*}$ Correspondence : Prodia Occupational Health Insitute, Jl. Kramat Raya 53, Jakarta, Indonesia \\ Email: aresenicosa10@gmail.com or mulyana@prodiaohi.co.id
}

\section{Abstract}

B

ACKGROUND: Recent studies have indicated that lead may affect activities on bone cells, but the mechanism is not yet clear. Therefore, we conducted a study to investigate correlation of chronic low-concentration lead exposure with bone turnover activity (ratio of C-telopeptide (CTx) and Procollagen Type 1 Amino-terminal Propeptide (P1NP) (CTx/P1NP)) and antioxidant (aminolevulinic acid (ALA) dehydratase (ALAD)) in a workers community.

METHODS: An observational study with cross-sectional design was carried out. Fifty two subjects from a workers community in Jakarta, Indonesia, had provided informed consents and undergone medical history, physical and laboratory examinations. Hair lead concentration was measured by Inductivelly Coupled Plasma Mass Spectrometry (ICP-MS) method. Meanwhile, P1NP was measured by Enzyme Immunoassay (EIA) method, ALAD was measured by Enzyme-linked immunosorbent assay (ELISA) and CTx was measured by Electro-chemiluminescence Immunoassay (ECLIA) method.

RESULTS: The mean hair lead concentration was $4.85 \mathrm{ppm}$. Based on Mayo Clinic reference, $28.85 \%$ of investigated subjects had hair lead concentration of $\geq$ $5 \mathrm{ppm}$. Hair lead concentration was not correlated with ALAD, CTx, P1NP concentrations or CTx/P1NP. ALAD concentration was significantly correlated with $\mathrm{CTx} / \mathrm{P} 1 \mathrm{NP}$ $(\mathrm{p}<0.05 ; \mathrm{r}=0.35)$.

\section{Abstrak}

$\mathrm{L}$ ATAR BELAKANG: Beberapa penelitian menunjukan bahwa timbal dapat mempengaruhi aktivitas sel-sel tulang, namun demikian mekanismenya belum jelas. Oleh karena itu, kami melakukan penelitian untuk menguji korelasi pajanan timbal dalam konsentrasi rendah secara kronis dengan aktivitas turnover tulang (rasio C-telopeptide (CTx) dan Procollagen Type 1 Amino-terminal Propeptide (P1NP) (CTx/P1NP)) dan antioksidan (aminolevulinic acid (ALA) dehydratase $(A L A D))$ pada komunitas pekerja.

METODE: Penelitian ini merupakan penelitian observasional dengan desain potong-lintang. Lima puluh dua subjek dari komunitas pekerja di Jakarta, Indonesia, telah melengkapi informed consent, riwayat kesehatan serta pemeriksaan fisik dan laboratorium. Konsentrasi timbal rambut diukur secara Inductivelly Coupled Plasma Mass Spectrometry (ICP-MS). P1NP diukur secara Enzyme Immunoassay (EIA), ALAD diukur secara Enzyme-linked immunosorbent assay (ELISA) dan CTx diukur secara Electro-chemiluminescence Immunoassay (ECLIA).

HASIL: rerata konsentrasi timbal rambut adalah 4,85 ppm. Berdasarkan nilai rujukan Mayo Clinic, 28,85\% subjek memiliki konsentrasi timbal rambut konsentrasi $\geq 5 \mathrm{ppm}$. Konsentrasi timbal rambut tidak berkorelasi dengan konsentrasi ALAD, CTx, P1NP maupun CTx/ P1NP. Konsentrasi ALAD berkorelasi signifikan dengan CTx/P1NP $(p<0,05 ; r=0,35)$. 
SUMMARY: ALAD concentration was correlated with $\mathrm{CTx} / \mathrm{P} 1 \mathrm{NP}$ ratio, indicating that the role of antioxidant was possibly caused by accumulated chronic lowconcentration lead exposure, which was correlated with bone turnover activity.

KEYWORDS: hair lead, ALAD, CTx, P1NP, osteoporosis, bone turnover

Indones Biomed J 2012; 4 (3): 180-185
KESIMPULAN: Konsentrasi ALAD berkorelasi dengan rasio CTx/P1NP, memperlihatkan bahwa peranan antioksidan yang kemungkinan akibat akumulasi pajanan timbal kronik, berkorelasi dengan aktivitas turnover tulang.

KATA KUNCI: timbal rambut, ALAD, CTx, P1NP, turnover tulang

Indones Biomed J 2012; 4 (3): 180-185

\section{Introduction}

Human activities contribute to the wide environmental spread of lead in the air, water, soil, plants, animals and man-made constructions (1). Some developing countries have problems associated with mining, smelting and refining of lead, as well as the use of leaded gasoline in motor vehicles. Therefore, individuals could get substantial lead exposure (2). Lead exposure to human may occur through a combination of inhalation and ingestion. Inhalation route is more common in the occupationally exposed groups than in the general community (3).

Leaded gasoline is the primary source of lead exposure in most developing countries. It accounts for $80-90 \%$ of airborne lead pollution in large cities. Lead removal from gasoline is the most effective way of preventing and eliminating lead. Approximately, 30 countries worldwide have phased out leaded gasoline (4), including Indonesia (5). A previous research showed that Indonesian children living in urban areas are at higher risk for having above acceptable blood lead concentration. As many as $26.7 \%$ of the children had lead concentration higher than $10 \mu \mathrm{g} / \mathrm{dL}$, and $2.4 \%$ had lead concentration higher than $20 \mu \mathrm{g} / \mathrm{dL}$ (6).

Lead potentially induces oxidative stress and more evidences support the role of oxidative stress in the pathophysiology of lead toxicity (7). Several epidemiological studies among workers with high occupational exposure to lead reported lead exposure is associated with oxidative stress markers. ALAD is one of antioxidant marker in lead exposure that inhibits prooxidant ALA biosynthesis in heme biosynthesis (8-10).

Various studies have shown that chronic low concentration lead exposure may have negative effects on the health of the general population $(9,11,12)$. Over time most of the lead accumulation in the human body is deposited in the bone, and it could be toxic due to its half-life of about 20 years $(13,14)$. Recently, long-lasting impact of lead has been demonstrated to interfere with bone formation and to increase the risk of osteoporosis in later life (15). Lead may affect bone cells function directly and bone turnover via kidney dysfunction indirectly (16). Although lead potentially increases the risk of osteoporosis, the mechanism is still not clear. Therefore, we conducted a study to investigate correlation of chronic low-concentration lead exposure with bone turnover activity and antioxidant (ALAD) in a workers community. Bone turnover activity can be calculated from ratio of bone resorption, CTx (17), and formation, P1NP (18) $(\mathrm{CT} x / \mathrm{P} 1 \mathrm{NP})(19)$.

\section{Methods}

\section{Study Design}

We performed an observational study with cross-sectional design on 52 subjects, i.e. 30-52 years old male workers in Jakarta, Indonesia. The subjects provided informed consents and underwent medical history, physical and laboratory examinations. Subjects with liver or renal impairments, hyperparatyroidism, diabetes mellitus or subjects receiving drugs altering bone metabolism, cholestyramine, phenobarbital, rifampicin, and phenytoin, were excluded from the study. The study protocol was approved by the Ethics Committee of Hasanuddin University, Reg No. UH12040062.

\section{ICP-MS}

Hair lead concentration was measured by using ICP-MS 
with technical parameters of American Public Health Association 3125B method (20). Briefly, 1 gram of hair was collected from $2 \mathrm{~mm}$ distance from the scalp of the nape. Collected hair specimens were washed with ethanol, packed in zip-lock bags and sent to ALS Lab, Malaysia. The detection limit of $1 \mathrm{ppm}$ was achieved.

\section{ELISA}

For ALAD measurement, blood was collected in heparin trace element-free vacuum tube. Tube was centrifuged at $1000 \mathrm{rpm}$ for 15 minutes at $4^{\circ} \mathrm{C}$, plasma was collected and refrigerated at $-20^{\circ} \mathrm{C}$. After all samples were collected, refrigerated plasma was thawed and centrifuged prior to ELISA (Recombinant Human Delta-aminolevulinic acid dehydratase (ALAD), Cusabio, catalog number CSBEL001558HU, China). ELISA was performed according to kit manual instruction. Coefficient of variation (CV) of ALAD measurement was $3.91 \%$.

For EIA P1NP measurement, blood was collected in clotting activator vacuum tube. Tube was kept in room temperature for 30 minutes, then centrifuged at 3,200 rpm for 10 minutes, serum was collected and refrigerated at $-20^{\circ} \mathrm{C}$. After all samples were collected, refrigerated serum was thawed and centrifuged prior to EIA (Total P1NP, Roche Diagnostic, catalog number 03141071190, Germany). EIA was performed according to kit manual instruction. Coefficient of variation (CV) of P1NP measurement was of $3.44 \%$.

\section{ECLIA}

For CTx measurement, refrigerated serum was thawed and centrifuged prior to ECLIA (Total B-Crosslaps/ serum, Roche Diagnostic, catalog number 11972308 122, Germany). ECLIA was performed according to kit manual instruction. Coefficient of variation (CV) of CTx measurement was $1.40 \%$

\section{Statistical Analysis}

We analyzed the data by descriptive and bivariate statistics using SPSS 15.0 for Windows. Continuous variables were expressed as mean, median, minimum-maximum and standard deviation. Pearson or Spearman correlation was used to determine the correlation of nominal variables. Statistical significance was considered at p-value $<0.05$.

\section{Results}

Subjects and biochemical characteristics of the study are shown in Table 1.The data showed that the mean of hair lead concentration was $4.85 \mathrm{ppm}$ (ranging from 1-36, median $=2, \mathrm{SD}=6.3$ ). The mean of $\mathrm{CT} \mathrm{x} / \mathrm{P} 1 \mathrm{NP}$ was 9.46 (ranging from 5.05-18.93, median $=9.01, \mathrm{SD}=2.56$ ). The mean of ALAD was $0.08 \mathrm{ng} / \mathrm{mL}$ (ranging from 0.071-0.1, median $=0.076, \mathrm{SD}=0.005$ ).

\section{Table 1. Subjects and Biochemical Characteristics}

\begin{tabular}{lccccc}
\hline Characteristics & Mean & Minimum & Median & Maximum & SD \\
\hline Age (year) & 36.73 & 30 & 35.5 & 52 & 6.22 \\
Body weight $(\mathrm{Kg})$ & 63.16 & 41.5 & 61.3 & 94 & 12.11 \\
Height $(\mathrm{m})$ & 1.65 & 1.52 & 1.65 & 1.83 & 0.06 \\
Body mass index $\left(\mathrm{Kg} / \mathrm{m}^{2}\right)$ & 23.10 & 17.69 & 22.54 & 32.91 & 3.63 \\
Waist circumference $(\mathrm{cm})$ & 81.39 & 62 & 80 & 100 & 10.21 \\
Systolic blood pressure $(\mathrm{mmHg})$ & 115.29 & 90 & 110 & 150 & 13.41 \\
Diastolic blood pressure (mmHg) & 76.63 & 60 & 80 & 100 & 9.94 \\
Hemoglobin (g/L) & 14.99 & 13 & 15 & 17.3 & 1.06 \\
Plasma fasting glucose (mg/dL) & 86.40 & 73 & 85 & 106 & 7.04 \\
Creatinin (mg/dL) & 0.89 & 0.71 & 0.88 & 1.27 & 0.11 \\
Serum Glutamic Pyruvate Transaminase (U/L) & 22.02 & 6 & 18 & 80 & 12.67 \\
ALAD $(\mathrm{ng} / \mathrm{mL})$ & 0.08 & 0.071 & 0.076 & 0.1 & 0.005 \\
Hair lead $(\mathrm{ppm})$ & 4.85 & 1 & 2 & 36 & 6.30 \\
CTx $(\mathrm{ng} / \mathrm{mL})$ & 0.48 & 0.161 & 0.489 & 0.838 & 0.17 \\
P1NP $(\mathrm{ng} / \mathrm{mL})$ & 51.97 & 25.46 & 51.46 & 98.67 & 17.02 \\
CTx/P1NP & 9.46 & 5.05 & 9.01 & 18.93 & 2.56 \\
& & & & & \\
\hline
\end{tabular}


Hair lead concentration was not significantly correlated with ALAD concentration, CTx, P1NP or CTx/P1NP. However, when hair lead concentration was increased, ALAD concentration increment was noticed as well (Figure 1). ALAD was significantly correlated with CTX/P1NP ratio $(\mathrm{p}<0.05)$ (Table 2).

Table 2. Results of Correlation Analysis

\begin{tabular}{lcc}
\hline \multicolumn{1}{c}{ Correlation } & $\mathbf{r}$ & $\mathbf{p}$ \\
\hline Hair lead concentration vs ALAD** & 0.18 & 0.21 \\
Hair lead concentration vs CTx & -0.10 & 0.48 \\
Hair lead concentration vs P1NP** & -0.12 & 0.40 \\
Hair lead concentration vs CTx/P1NP** & 0.10 & \\
& & \\
ALAD vs CTx*** & 0.01 & 0.95 \\
ALAD vs P1NP & -0.22 & 0.12 \\
ALAD vs CTx/P1NP ratio** & 0.35 & $0.01^{*}$ \\
& & \\
\hline
\end{tabular}

${ }^{*} p<0.05 ;{ }^{* *}$ Spearman correlation, ${ }^{* * *}$ Pearson correlation

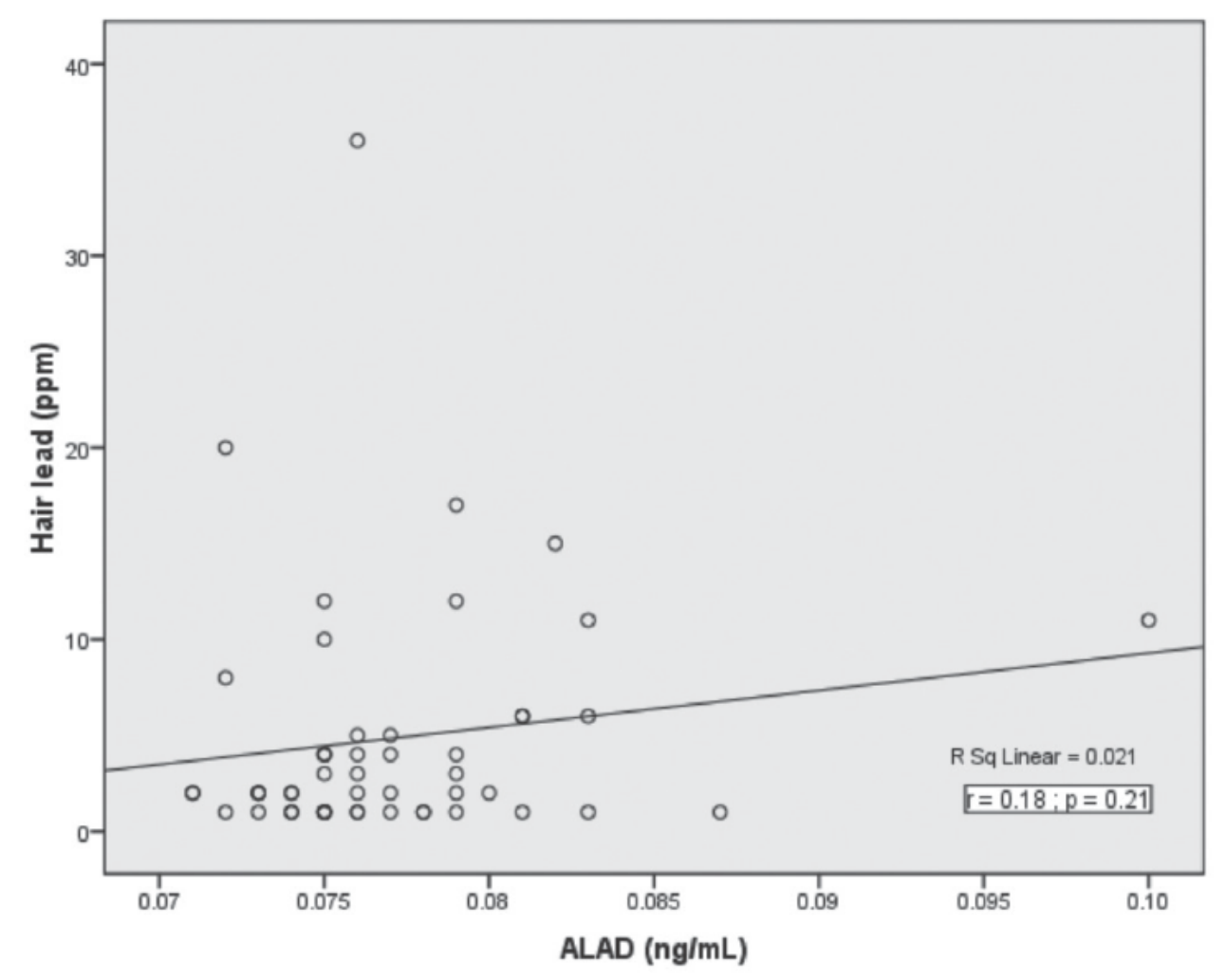

Figure 1. Correlation of Hair Lead with ALAD 


\section{Discussion}

Based on Mayo Clinic reference (17), $28.85 \%$ of investigated subjects had hair lead concentration $\geq 5 \mathrm{ppm}$. Meanwhile, Badan Pengelolaan Lingkungan Hidup Daerah (BPLHD) Jakarta, reported ambient air lead concentrations were ranging from $0.011-0.036 \mu \mathrm{g} / \mathrm{m}^{3}(21)$, still below the permissible exposure limit of $<2 \mu \mathrm{g} / \mathrm{m}^{3}$. The sources of lead contaminations in this study were not identified specifically, but they may constitute contaminated food or drinking water, vehicle emissions, paintings, or industries.

Biomonitoring of human exposure to lead reflects an individual's current body burden due to recent and/ or past exposure. Lead body burden is better reflected from element content in the hair or nail-than that in blood, because hair and nail retain the record of relatively long period of exposure, while blood shows transient concentration that changes with time (22). Hair is advantageous as it is inert and easier to be sampled than blood or teeth, and can be stored without much technicality. Hair lead concentration was high and positively correlated with bone lead concentration in rats (23).

Chronic lead toxicity causes some health disorders such as hypertension $(16,24)$, osteoporosis, (15) etc. Although hair lead concentration reflects chronic lead toxicity, in this study, hair lead concentration was not significantly correlated with CTx, P1NP or CTx/P1NP. In the other studies, lead was reported to induce osteoporosis at high concentration of $>20 \mathrm{ppm}$ (10). Therefore chronic low-concentration lead exposure on hair may not good enough as osteoporosis marker.

One of the effects of lead toxicity is oxidative stress $(9,11)$. Oxidative stress appears to be a possible mode of the molecular mechanism of lead toxicity. Oxidative stress occurs when generation of free radicals exceed the capacity of antioxidant defense mechanism. Depletion of glutathione and protein-bound sulfuhydril groups and change in the activity of the various antioxidant-enzymes indicative-of-lipid-peroxidation have been implicated in lead-induced oxidative tissue damage (8). Stress oxidative status could be a risk for osteoporosis (25). ALAD is more specific antioxidant in lead toxicity. The key findings in this study were that ALAD as antioxidant marker in lead poisoning was significantly correlated with CTX/ P1NP. Since accumulated chronic low-concentration lead exposure is being deposited in bone $(13,14)$, oxidative stress may later be induced which later will be correlated with bone turnover activity. However, further study with a greater number of subjects with more antioxidant markers are necessary for better understanding on lead toxicity.

\section{Conclusions}

ALAD concentration as antioxidant marker was significantly correlated with $\mathrm{CTx} / \mathrm{P} 1 \mathrm{NP}$, indicating that the role of antioxidant may possibly be caused by accumulated chronic low-concentration lead exposure, which was correlated with bone turnover activity.

\section{Acknowledgements:}

This study was funded by Prodia Clinical laboratory. We would like to thank the Prodia Education and Research Institute, Research Support Departement of Prodia Clinical Laboratory, Prodia Clinical Laboratory Kramat Branch and Prodia Occupational Health Institute for their invaluable supports.

\section{References:}

1. Skerfving S, Bergdahl I. Lead. In: Nordberg GF, Fowler BA, Nordberg M, Friberg LT, editors. Handbook on the toxicology of metals. London: Elsevier; 2007. P. 599-651.

2. Kaul B. Lead exposure and iron deficiency among Jammu and New Delhi children. Indian J Pediatr. 1999; 66: 27-35.

3. Neo KS, Goh KT, Sam CT. Blood lead levels of a population group not occupationally exposed to lead in Singapore. Southeast Asian J Trop Med Public Health. 2000; 31: 295-300.

4. Lovei M. Eliminating a silent threat: World Bank support for the global phase-out of lead from gasoline. Lead Poisoning Prevention and Treatment: Implementing a National Program in Developing Countries. Proceedings of the International Conference on Lead Poisoning Prevention and Treatment. Bangalore: The George Foundation; 1999. p. $169-80$.

5. Heinze I, Gross R, Stehle P, Dillon D. Assessment of lead exposure in school children from Jakarta. Environ Health Perspect. 1998; 106: 499-501.

6. Albalak R, Noonan G, Buchanan S, Flanders WD, GotwayCrawford C Kim D, et al. Blood lead levels and risk factors for lead poisoning among children in Jakarta, Indonesia. Sci Total Environ. 2003; 301: 75-85.

7. Flora SJ, Pande M, Kannan GM, Mehta A. Lead induced oxidative stress and its recovery following $\mathrm{Co}$ administration of melatonin or n-acetylcysteine during chelation with succimer in male rats. Cell Mol Biol. 2004; 50: 543-51.

8. Ahamed M, Siddiqui MKJ. Low level lead exposure and oxidative stress: current opinions. Clin Chim Acta. 2007; 383: 57-64.

9. Gurer-Orhan H, Sabir HU, Ozgunez H. Correlation between clinical indicator of lead poisoning and oxidative stress parameters in controls and lead exposed workers. Toxicology, 2004; 195: 147-54.

10. Mohammad I, Mahdi A, Raviraja A, Najmu I, Iqbal A, Thuppil V. Oxidative stress in painters exposed to low lead levels. Arh Hig Rada Toksikol 2008; 59: 161-9.

11. Adanaylo VN, Oteiza $\mathrm{PI}$. $\mathrm{Pb}^{2+}$ promotes lipid peroxidation and alteration in membrane physical properties. Toxicology. 2002; 132: 19-32.

12. Kaewboonchoo O, Saleekul S, Powwattana A, Kawai T. Blood lead level and blood pressure of bus drivers in Bangkok, Thailand. Ind Health. 2007; 45: 590-4.

13. Rabinowitz MB. Toxicokinetics of bone lead. Environ Health Perspect. 1991; 91: 33-7. 
14. Berglund M, Akesson A, Bjellerup P, Vahter M. Metal-bone interactions. Toxicol lett. 2000; 112: 219-25.

15. Sun Y, Sun DH, Zhou ZJ, Zhu GY, Zhang HY, et al. Osteoporosis in a Chinese due to occupational lead exposure. Am J Ind Med. 2008; 51: 436-42.

16. Goyer RA. Lead toxicity: current concerns. Environ Health Perspect. 1993; 100: 177-87.

17. Garnero P. Markers of bone turnover for monitoring antiresorptive treatment of osteoporosis. J Menopause. 2001; 7: 49-51.

18. Mayo Medical Laboratories. Rochester 2013 Interpretive Handbook. Rochester: Mayo Foundation for Medical Education and Research; 2013.

19. Monagolas SC, Jilka RL. Bone marrow cytokines and bone remodelling emerging insights into the pathophysiology of osteoporosis. N Eng J Med. 1995; 332: 305-10.

20. American Public Health Association. Standard methods for water and waste water, $3125 \mathrm{~B}$ method. Washington DC: American Public Health Association; 1998.
21. Badan Pengelola Lingkungan Hidup Daerah Provinsi DKI Jakarta. Laporan status lingkungan hidup daerah Provinsi DKI Jakarta tahun 2010. Jakarta: Pemerintah Provinsi DKI Jakarta; 2010.

22. Mehra R, Juneja M. Biological monitoring of lead and cadmium in human hair and nail and their correlations with biopsy materials, age and exposure. Indian J Biochem Biophys. 2004;41: 53-6.

23. Krejpcio Z, Gawecki J. Hair lead and body lead burden in leadintoxicated rats fed diets enriched with dietary fibre. Pol J Environ Stud. 2002; 11:123-26

24. Preuss HG. A review of persistent, low-grade lead challenge: neurological and cardiovascular consequences. J Am Coll Nutr. 1993; 12: 246-54.

25. Sánchez-Rodríguez MA, Ruiz-Ramos M, Correa-Muñoz $E$, Mendoza-Núñez VM. Oxidative stress as a risk Factor for osteoporosis in elderly mexicans as characterized by antioxidant enzymes. BMC Musculoskelet Disord. 2007; $8: 1-7$. 